\title{
Urinary tumor markers for diagnosis of prostate cancer
}

\author{
Mine Ün ${ }^{1}$ (D), Mustafa $\operatorname{Sel}^{2}$ (D) \\ ${ }^{1}$ Istanbul Aydin University Medical Faculty, Istanbul, Turkey \\ ${ }^{2}$ Biruni University Medical Faculty, Istanbul, Turkey
}

\begin{abstract}
Prostate cancer is currently one of the most common health problems in the male population. It holds place as the most commonly diagnosed cancer in the United States and most regions worldwide and is the second most common cause of cancer-related deaths in males. High incidence of this cancer has brought developments in diagnostic and treatment methods. The most important screening method in diagnosis is measurement of serum prostate specific antigen (PSA). Digital rectal examination is also an important component of diagnosis. While PSA is the most important diagnostic method, it is specific to the prostate but not specific to prostate cancer. Elevated PSA levels may also occur in benign prostate hyperplasia (BPH) and inflammation of the prostate gland. In other words, PSA is a method with low specificity that does not only increase in prostate cancer and may result in false positives and unnecessary biopsies. Therefore, new markers for the diagnosis of prostate cancer are being researched. For this purpose, it has been observed that many proteins, molecules, DNA and RNA markers in urine can be used in the diagnosis of prostate cancer.

Keywords: MicroRNA, non-PSA biomarkers, prostate cancer.
\end{abstract}

Prostate cancer is the most common solid tissue cancer in Western populations. Its high incidence has increased the importance given to diagnosis. The most commonly used method in diagnosis is measurement of prostate specific antigen (PSA). ${ }^{[1]}$

The widespread use of PSA has significantly reduced metastases and deaths due to prostate cancer. ${ }^{[1]}$ Although PSA is specific to the prostate organ, it is not specific to prostate cancer. In other words, serum PSA levels may increase in some diseases other than prostate cancer (such as benign prostate enlargement, and inflammation of the prostate gland). This leads to the diagnosis and unnecessary treatment of clinically insignificant prostate cancers. ${ }^{[2,3]}$

For these reasons, serum PSA measurement alone does not carry the ideal specificity for detecting prostate cancer. This limitation of serum PSA measurement has increased the search for markers with higher specificity that can detect high risk prostate cancers, which are the main target for treatment. ${ }^{[2,3]}$

\section{NON-PSA TUMOR MARKERS}

In the last decade there have been promising developments in the clinical use of new markers that can be measured in urine and are more specific to prostate cancer. ${ }^{[4]}$

To date, many molecules found in urine have been studied on this subject (Table 1). ${ }^{[4]}$

During the period of molecular studies for the diagnosis of prostate cancer, microribonucleic acid (microRNAs) were found to be involved in the regulation of many basic cellular functions, however, abnormal miRNA levels in the cell were found to be associated with cancer development in humans. Therefore, it was established that microRNAs have a function as oncogenes or tumor suppressors in tumor development. ${ }^{[4]}$ 
Considering the localization and expression profiles of most miRNAs, they were predicted to have a key role in cancer formation. ${ }^{[5,6]}$

The expression profile of many genes in a certain tumor can be extracted by robotic technologies (microarray), with the prediction of miRNome members, and even the fingerprint of the tumor being investigated can be determined. ${ }^{[7]}$

\section{MARKERS FOUND IN URINE}

Markers found in urine are used in screening, diagnosis, and treatment of prostate cancer. Easy obtainment of urine has increased the interest in these markers. ${ }^{[8,9]}$ Urine-based markers are evaluated in three groups: protein-based, deoxyribonucleic acid (DNA)-based, and RNAbased (Table 1). ${ }^{[10-12]}$

\section{Protein based markers}

Protein based biomarkers in urine (Annexin A3, matrix metalloproteinases, and urine/serum PSA ratio) have conflicting results. Detailed evaluation of human urine has shown that there are over 1,500 types of protein and that use of these proteins as biomarkers is relatively difficult. ${ }^{[11]}$

\section{Annexin A3}

Annexin A3 is responsible for tumor formation and migration. It has been found to be negatively correlated with ovarian cancer and colon cancer. ${ }^{[13]}$

Annexin A3 has been shown in urine in prostate cancer with the Western-blot method. ${ }^{[14]}$ Annexin A3 is tested in addition to serum PSA and is negatively correlated with prostate cancer. A combination of both Annexin A3 and PSA tests compared to PSA alone has been proven more effective in diagnosing prostate cancer. ${ }^{[14]}$

\section{Matrix metalloproteinases}

Matrix metalloproteinases have an important role in the growth, invasion, and metastasis of some tumors. ${ }^{[15]}$ Roy et al. ${ }^{[16]}$ reported that $82 \%$ specificity and $74 \%$ sensitivity of matrix metalloproteinases in urine.

\section{Urine PSA}

Prostate specific antigen was first detected in urine in the 1980s. ${ }^{[17]}$ Despite intensive research on serum PSA, there have not been enough studies on PSA in urine. ${ }^{[18]}$

Prostate specific antigen detected in initial urine stream has been found to better represent local PSA production compared to PSA obtained from mid- and end-stream urine. ${ }^{[18]}$

Studies have shown that urinary PSA is more valuable than serum PSA in prostate cancer diagnosis. ${ }^{[19,20]}$

\section{Deoxyribonucleic acid based markers}

Studies on DNA based markers in urine have especially focused on methylation and hypermethylation of Glutathione S-transferase $\pi$ (GSTP1). ${ }^{[12]}$

\section{Glutathione S-transferase $\pi$}

Enzymes of the Glutathione S-transferase family have important effects on cell metabolism. One of the most important effects is the removal of harmful substrates from the body. ${ }^{[21]}$

Lee et al. ${ }^{[22]}$ showed hypermethylation of the regulatory sequences of the GSTP1 gene in all prostate cancer tissue samples. In addition, while increased GSTP1 production is observed in normal prostate epithelium, decreased GSTP1 production is observed in prostate cancer epithelium. ${ }^{[22]}$ These studies suggested that evaluation of methylation

Table 1. Prostate cancer markers in urine

\begin{tabular}{lll}
\hline Protein based & DNA based & RNA based \\
\hline Annexin A3 & GSTP1 & PCA-3 test \\
Matrix metalloproteinases & Hypermethylation & TMPRSS2-ERG gene fusion \\
Urine/serum PSA ratio & & GOLPH2 transcript expression levels \\
& & SPINK 1 \\
\hline
\end{tabular}

DNA: Deoxyribonucleic acid; RNA: Ribonucleic acid; GSTP1: Glutathione S-transferase $\pi$; PCA-3: Prostate cancer antigen-3; TMPRSS2: Transmembrane protease, serine 2; ERG: v-ets erythroblastosis virus E26 oncogene homolog; PSA: Prostate specific antigen; GOLPH2: Golgi phosphoprotein 2; SPINK1: Serine protease inhibitor Kazal type 1. 
of GSTP1 may be a useful tumor marker in screening prostate cancer. ${ }^{[23-26]}$

\section{Ribonucleic acid based markers}

Ribonucleic acid based markers are the most commonly researched group. Among them, the PCA-3 test, transmembrane protease, serine 2-v-ets erythroblastosis virus E26 oncogene homolog (TMPRSS2-ERG) gene fusion, Golgi phosphoprotein 2 (GOLPH2) transcription expression levels, and serine protease inhibitor Kazal type 1 (SPINK1) and combinations are the most notable. ${ }^{[10]}$ However, the PCA-3 test stands out the most in most studies. ${ }^{[8,9]}$

\section{Prostate cancer antigen-3 (PCA-3)}

Prostate Cancer Antigen-3, or PCA-3, was first isolated from prostate cancer tissue in the 1990s. Its use as a potential biomarker for prostate cancer came into question in 1999, with findings of increased PCA-3 mRNA production in the prostate compared to normal tissue. Prostate cancer antigen (PCA-3) is a non-coding RNA on chromosome 9 and is the most specific marker for prostate cancer in clinical use today. The production of PCA-3 RNA occurs only in prostate tissue and is not found in any other organs or tumors in humans. ${ }^{[27]}$

Numerous studies have shown that PCA-3 is produced 66 times more than normal tissue in prostate cancer tissue, and 11-fold increase in prostate cancer specificity even in prostates with less than $10 \%$ cancer cells has drawn attention. ${ }^{[28]}$

In coming years, due to its high specificity for prostate cancer, PCA-3 in conjunction with other biomarkers is a candidate for becoming an important guide in the treatment of prostate cancer patients. ${ }^{[28-34]}$

\section{TMPRSS2-ERG gene transfusion}

There is evidence that TMPRSS2 plays an important role in the rearrangement of genes in the initial stages of cancer development. In recent years, presence of fusion between androgendependent transmembrane serine 2 (TMPRSS2) gene and ERG gene of the ETS family has been shown in prostate cancer. ${ }^{[35]}$

ERG is an oncogene that plays a key role in the development of prostate cancer, and gene fusion between TMPRSS2 and ERG is the most commonly encountered genetic disorder. These two genes are located on chromosome 21 and fusion occurs when there is DNA loss. ${ }^{[36]}$ As fusion of these genes has been shown to have an impact on the development of prostate cancer, their use as a biomarker has become a current issue. ${ }^{[37]}$

TMPRSS2-ERG gene fusion, as in PCA-3, can be detected in urine following prostate massage. One study showed TMPRSS2-ERG gene fusion in urine samples after prostate massage in eight of 19 prostate cancer patients. ${ }^{[37-40]}$

While TMPRSS2-ERG is promising in differentiating patients with prostate cancer from those without prostate cancer due to its high specificity, there is need for more comprehensive

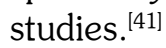

\section{miRNA in prostate cancer}

Another interesting and complex subject in prostate cancer is micro-RNA or non-coding RNAs. ${ }^{[42]}$ Micro-RNAs (miR) are small, non-coding RNAs that regulate production of protein-coding genes. They are a potential marker for tumor formation and metastasis. ${ }^{[43]}$

MiR21, miR125b, miR221, and miR222 belong to the oncogenic microRNA family and are associated with aggressive prostate cancer. ${ }^{[44]}$

MiR21 suppresses tumor suppressor genes, regulating tumor growth in prostate cancer. ${ }^{[45]}$ Sun et al. ${ }^{[46]}$ showed increased tendency of general expression of miRNAs in prostate cancer. MiR21 expression was found to be significantly increased in all tumor tissues, especially prostate cancer. ${ }^{[47-49]}$ Galardi et al. ${ }^{[50]}$ found increased expression of miR221/222 in prostate cancer, similar to miR21. ${ }^{[51-55]}$ Micro-RNAs are predicted to be used as both biomarkers and a tool for target-specific treatment individualized to the patient. Combination of miRNA and PSA can be useful in diagnosing prostate cancer. However, it is difficult to obtain nucleic acid and it is difficult to make miRNA studies available in clinical practice due to limited use. ${ }^{[50-55]}$

In conclusion, considering the changes in miRNA expression in tumor tissues and the mRNAs they target, evidence of significant benefit of these small, non-coding RNAs in early diagnosis and development of therapeutic agents has emerged. However, in order to benefit from 
miRNAs as a biomarker of cancer development or as therapeutic agents, the findings must be brought to certain standards. As the ongoing search for new biomarkers continues, cost analyses must also be considered.

\section{Declaration of conflicting interests}

The authors declared no conflicts of interest with respect to the authorship and/or publication of this article.

\section{Funding}

The authors received no financial support for the research and/or authorship of this article.

\section{REFERENCES}

1. Jemal A, Siegel R, Ward E, Hao Y, Xu J, Thun MJ. Cancer statistics, 2009. CA Cancer J Clin 2009;59:225-49.

2. Stamey TA, Caldwell M, McNeal JE, Nolley R, Hemenez M, Downs J. The prostate specific antigen era in the United States is over for prostate cancer: what happened in the last 20 years? J Urol 2004;172:1297-301.

3. Andriole GL, Crawford ED, Grubb RL 3rd, Buys SS, Chia D, Church TR, et al. Prostate cancer screening in the randomized Prostate, Lung, Colorectal, and Ovarian Cancer Screening Trial: mortality results after 13 years of follow-up. J Natl Cancer Inst 2012;104:125-32.

4. Wijnhoven BP, Michael MZ, Watson DI. MicroRNAs and cancer. Br J Surg 2007;94:23-30.

5. Sevignani C, Calin GA, Siracusa LD, Croce CM. Mammalian microRNAs: a small world for fine-tuning gene expression. Mamm Genome 2006;17:189-202.

6. Calin GA. MicroRNAs and cancer: what we know and what we still have to learn. Genome Med 2009;1:78.

7. Aqeilan RI, Calin GA, Croce CM. miR-15a and miR-16-1 in cancer: discovery, function and future perspectives. Cell Death Differ 2010;17:215-20.

8. Demichelis F, Fall K, Perner S, Andrén O, Schmidt F, Setlur SR, et al. TMPRSS2:ERG gene fusion associated with lethal prostate cancer in a watchful waiting cohort. Oncogene 2007;26:4596-9.

9. Auprich M, Bjartell A, Chun FK, de la Taille A, Freedland SJ, Haese A, et al. Contemporary role of prostate cancer antigen 3 in the management of prostate cancer. Eur Urol 2011;60:1045-54.

10. Roobol MJ, Haese A, Bjartell A. Tumour markers in prostate cancer III: biomarkers in urine. Acta Oncol 2011;50:85-9.

11. Adachi J, Kumar C, Zhang Y, Olsen JV, Mann M. The human urinary proteome contains more than 1500 proteins, including a large proportion of membrane proteins. Genome Biol 2006;7:R80.
12. Payne SR, Serth J, Schostak M, Kamradt J, Strauss $\mathrm{A}$, Thelen $\mathrm{P}$, et al. DNA methylation biomarkers of prostate cancer: confirmation of candidates and evidence urine is the most sensitive body fluid for noninvasive detection. Prostate 2009;69:1257-69.

13. Madoz-Gúrpide J, López-Serra P, MartínezTorrecuadrada JL, Sánchez L, Lombardía L, Casal JI. Proteomics-based validation of genomic data: applications in colorectal cancer diagnosis. Mol Cell Proteomics 2006;5:1471-83.

14. Schostak M, Schwall GP, Poznanovic S, Groebe K, Müller M, Messinger D, et al. Annexin A3 in urine: a highly specific noninvasive marker for prostate cancer early detection. J Urol 2009;181:343-53.

15. Egeblad M, Werb Z. New functions for the matrix metalloproteinases in cancer progression. Nat Rev Cancer 2002;2:161-74.

16. Roy R, Louis G, Loughlin KR, Wiederschain D, Kilroy SM, Lamb CC, et al. Tumor-specific urinary matrix metalloproteinase fingerprinting: identification of high molecular weight urinary matrix metalloproteinase species. Clin Cancer Res 2008;14:6610-7.

17. Graves HC, Sensabaugh GF, Blake ET. Postcoital detection of a male-specific semen protein. Application to the investigation of rape. N Engl J Med 1985;312:338-43.

18. Iwakiri J, Granbois K, Wehner N, Graves HC, Stamey $\mathrm{T}$. An analysis of urinary prostate specific antigen before and after radical prostatectomy: evidence for secretion of prostate specific antigen by the periurethral glands. J Urol 1993;149:783-6.

19. Bolduc S, Lacombe L, Naud A, Grégoire M, Fradet Y, Tremblay RR. Urinary PSA: a potential useful marker when serum PSA is between $2.5 \mathrm{ng} / \mathrm{mL}$ and $10 \mathrm{ng} /$ mL. Can Urol Assoc J 2007;1:377-81.

20. Irani J, Salomon L, Soulié M, Zlotta A, de la Taille A, Doré $\mathrm{B}$, et al. Urinary/serum prostate-specific antigen ratio: comparison with free/total serum prostatespecific antigen ratio in improving prostate cancer detection. Urology 2005;65:533-7.

21. Jakoby WB. The glutathione S-transferases: a group of multifunctional detoxification proteins. Adv Enzymol Relat Areas Mol Biol 1978;46:383-414.

22. Lee WH, Morton RA, Epstein JI, Brooks JD, Campbell $\mathrm{PA}$, Bova GS, et al. Cytidine methylation of regulatory sequences near the pi-class glutathione S-transferase gene accompanies human prostatic carcinogenesis. Proc Natl Acad Sci U S A 1994;91:11733-7.

23. Harden SV, Guo Z, Epstein JI, Sidransky D. Quantitative GSTP1 methylation clearly distinguishes benign prostatic tissue and limited prostate adenocarcinoma. J Urol 2003;169:1138-42.

24. Gonzalgo ML, Pavlovich CP, Lee SM, Nelson WG. Prostate cancer detection by GSTP1 methylation analysis of postbiopsy urine specimens. Clin Cancer Res 2003;9:2673-7.

25. Bastian PJ, Palapattu GS, Lin X, Yegnasubramanian S, Mangold LA, Trock B, et al. Preoperative serum 
DNA GSTP1 CpG island hypermethylation and the risk of early prostate-specific antigen recurrence following radical prostatectomy. Clin Cancer Res 2005;11:4037-43.

26. Trock BJ, Brotzman MJ, Mangold LA, Bigley JW, Epstein JI, McLeod D, et al. Evaluation of GSTP1 and APC methylation as indicators for repeat biopsy in a high-risk cohort of men with negative initial prostate biopsies. BJU Int 2012;110:56-62.

27. Bussemakers MJ, van Bokhoven A, Verhaegh GW, Smit FP, Karthaus HF, Schalken JA, et al. DD3: a new prostate-specific gene, highly overexpressed in prostate cancer. Cancer Res 1999;59:5975-9.

28. Hessels D, Klein Gunnewiek JM, van Oort I, Karthaus HF, van Leenders GJ, van Balken B, et al. DD3(PCA3)based molecular urine analysis for the diagnosis of prostate cancer. Eur Urol 2003;44:8-15

29. Groskopf J, Aubin SM, Deras IL, Blase A, Bodrug S, Clark C, et al. APTIMA PCA3 molecular urine test: development of a method to aid in the diagnosis of prostate cancer. Clin Chem 2006;52:1089-95.

30. Deras IL, Aubin SM, Blase A, Day JR, Koo S, Partin AW, et al. PCA3: a molecular urine assay for predicting prostate biopsy outcome. J Urol 2008;179:1587-92.

31. Haese A, de la Taille A, van Poppel $H$, Marberger M, Stenzl A, Mulders PF, et al. Clinical utility of the PCA3 urine assay in European men scheduled for repeat biopsy. Eur Urol 2008;54:1081-8.

32. Perdonà S, Cavadas V, Di Lorenzo G, Damiano R, Chiappetta G, Del Prete P, et al. Prostate cancer detection in the "grey area" of prostate-specific antigen below $10 \mathrm{ng} / \mathrm{ml}$ : head-to-head comparison of the updated PCPT calculator and Chun's nomogram, two risk estimators incorporating prostate cancer antigen 3. Eur Urol 2011;59:81-7.

33. Salagierski M, Schalken JA. Molecular diagnosis of prostate cancer: PCA3 and TMPRSS2:ERG gene fusion. J Urol 2012;187:795-801.

34. Hessels D, Schalken JA. The use of PCA3 in the diagnosis of prostate cancer. Nat Rev Urol 2009;6:255-61.

35. Tomlins SA, Rhodes DR, Perner S, Dhanasekaran SM, Mehra R, Sun XW, et al. Recurrent fusion of TMPRSS2 and ETS transcription factor genes in prostate cancer. Science 2005;310:644-8.

36. Perner S, Demichelis F, Beroukhim R, Schmidt $\mathrm{FH}$, Mosquera JM, Setlur S, et al. TMPRSS2:ERG fusion-associated deletions provide insight into the heterogeneity of prostate cancer. Cancer Res 2006;66:8337-41.

37. Laxman B, Tomlins SA, Mehra R, Morris DS, Wang L, Helgeson BE, et al. Noninvasive detection of TMPRSS2:ERG fusion transcripts in the urine of men with prostate cancer. Neoplasia 2006;8:885-8.

38. Hessels D, Smit FP, Verhaegh GW, Witjes JA, Cornel EB, Schalken JA. Detection of TMPRSS2-ERG fusion transcripts and prostate cancer antigen 3 in urinary sediments may improve diagnosis of prostate cancer. Clin Cancer Res 2007;13:5103-8.

39. Karnes RJ, Cheville JC, Ida CM, Sebo TJ, Nair AA, Tang $\mathrm{H}$, et al. The ability of biomarkers to predict systemic progression in men with high-risk prostate cancer treated surgically is dependent on ERG status. Cancer Res 2010;70:8994-9002.

40. Attard G, Swennenhuis JF, Olmos D, Reid AH, Vickers E, A'Hern R, et al. Characterization of ERG, $\mathrm{AR}$ and PTEN gene status in circulating tumor cells from patients with castration-resistant prostate cancer. Cancer Res 2009;69:2912-8.

41. Gopalan A, Leversha MA, Satagopan JM, Zhou $\mathrm{Q}$, Al-Ahmadie HA, Fine SW, et al. TMPRSS2ERG gene fusion is not associated with outcome in patients treated by prostatectomy. Cancer Res 2009;69:1400-6.

42. Gandellini P, Folini M, Zaffaroni N. Emerging role of microRNAs in prostate cancer: implications for personalized medicine. Discov Med 2010;9:212-8.

43. Catto JW, Alcaraz A, Bjartell AS, De Vere White $\mathrm{R}$, Evans CP, Fussel S, et al. MicroRNA in prostate, bladder, and kidney cancer: a systematic review. Eur Urol 2011;59:671-81.

44. Felli N, Fontana L, Pelosi E, Botta R, Bonci D, Facchiano F, et al. MicroRNAs 221 and 222 inhibit normal erythropoiesis and erythroleukemic cell growth via kit receptor down-modulation. Proc Natl Acad Sci U S A 2005;102:18081-6.

45. Nikitina EG, Urazova LN, Stegny VN. MicroRNAs and human cancer. Exp Oncol 2012;34:2-8.

46. Sun R, Fu X, Li Y, Xie Y, Mao Y. Global gene expression analysis reveals reduced abundance of putative microRNA targets in human prostate tumours. BMC Genomics 2009;10:93.

47. Volinia S, Calin GA, Liu CG, Ambs S, Cimmino A, Petrocca $F$, et al. A microRNA expression signature of human solid tumors defines cancer gene targets. Proc Natl Acad Sci U S A 2006;103:2257-61.

48. Ribas J, Ni X, Haffner M, Wentzel EA, Salmasi AH, Chowdhury WH, et al. miR-21: an androgen receptorregulated microRNA that promotes hormonedependent and hormone-independent prostate cancer growth. Cancer Res 2009;69:7165-9.

49. Li T, Li D, Sha J, Sun P, Huang Y. MicroRNA-21 directly targets MARCKS and promotes apoptosis resistance and invasion in prostate cancer cells. Biochem Biophys Res Commun 2009;383:280-5.

50. Galardi S, Mercatelli N, Giorda E, Massalini S, Frajese GV, Ciafrè SA, et al. miR-221 and miR-222 expression affects the proliferation potential of human prostate carcinoma cell lines by targeting p27Kip1. J Biol Chem 2007;282:23716-24.

51. Mercatelli N, Coppola V, Bonci D, Miele F, Costantini A, Guadagnoli $\mathrm{M}$, et al. The inhibition of the highly expressed miR-221 and miR-222 impairs the growth of prostate carcinoma xenografts in mice. PLoS One 2008;3:e4029. 
52. Hu L, Ibrahim S, Liu C, Skaar J, Pagano M, Karpatkin $\mathrm{S}$. Thrombin induces tumor cell cycle activation and spontaneous growth by down-regulation of p27Kip1, in association with the up-regulation of Skp2 and MiR222. Cancer Res 2009;69:3374-81.

53. Sun T, Wang Q, Balk S, Brown M, Lee GS, Kantoff $\mathrm{P}$. The role of microRNA-221 and microRNA-222 in androgen-independent prostate cancer cell lines. Cancer Res 2009;69:3356-63.
54. Yoshino T, Shiina H, Urakami S, Kikuno N, Yoneda $\mathrm{T}$, Shigeno $\mathrm{K}$, et al. $\mathrm{Bcl}-2$ expression as a predictive marker of hormone-refractory prostate cancer treated with taxane-based chemotherapy. Clin Cancer Res 2006;12:6116-24.

55. DeVere White RW, Vinall RL, Tepper CG, Shi XB. MicroRNAs and their potential for translation in prostate cancer. Urol Oncol 2009;27:307-11. 